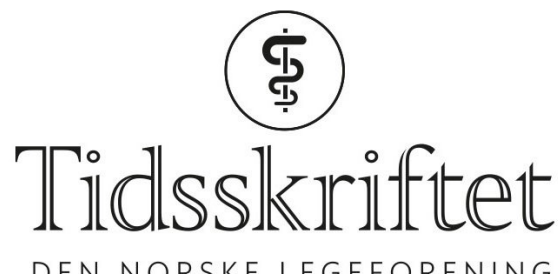

DEN NORSKE LEGEFORENING

\title{
En president for alle
}

INTERVJU

MARIT TVEITO

E-post: marit.tveito@aldringoghelse.no

Nasjonal kompetansetjeneste for aldring og helse

Sykehusstreik, fastlegekrise og pandemi. Læringskurven har vært bratt for Marit Hermansen etter at hun ble president i Legeforeningen i 2015.

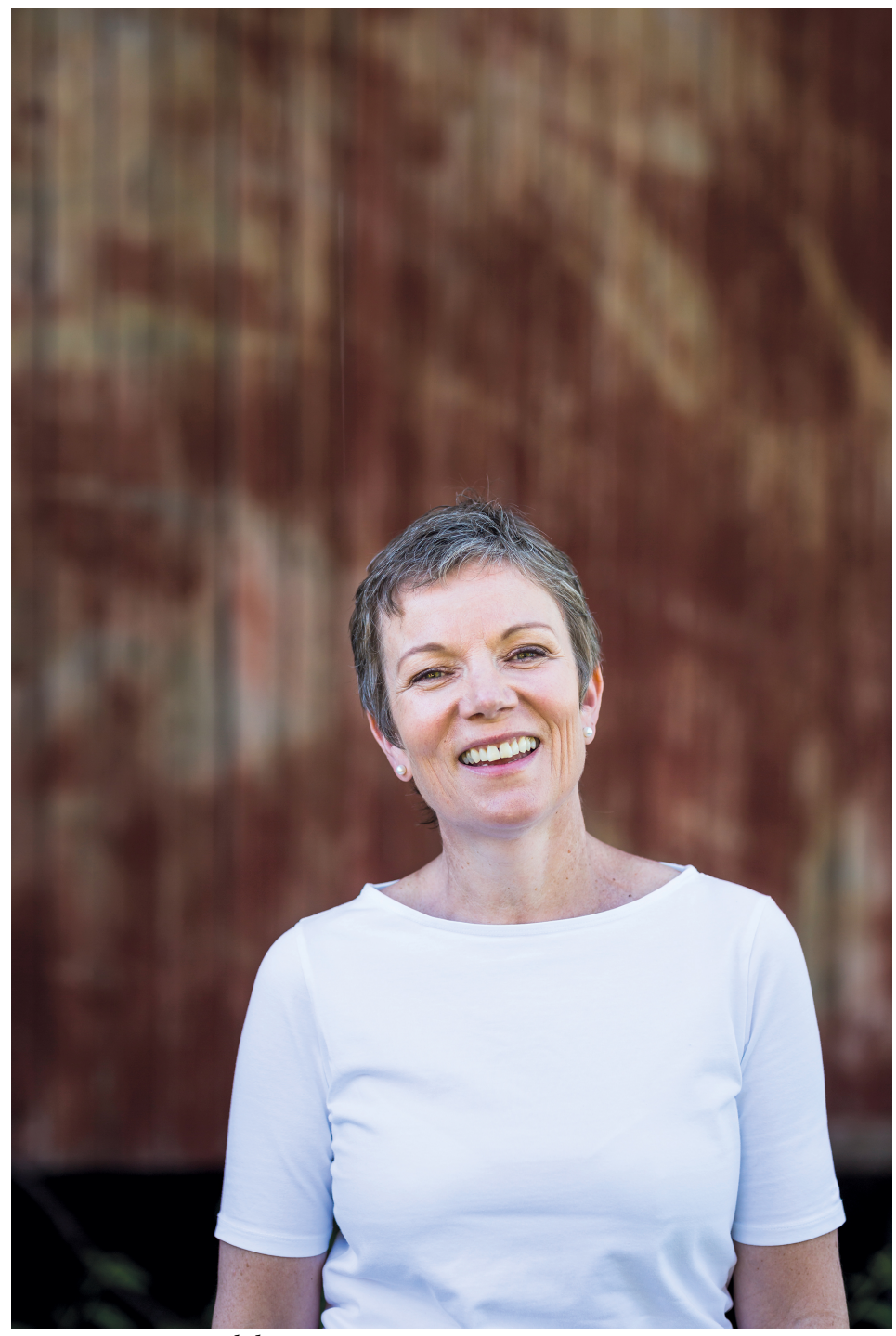

Foto: Kristine Lindebøe

Folk som kjenner Marit Hermansen, sier hun er som hun fremstår - jordnær og bunnsolid. 
Ujålete og flink. Alltid seg selv, enten hun snakker med helseministeren, tillitsvalgte eller pasienter. Kolleger fra foreningen trekker frem at hun er en samlende president, som har vunnet respekt i alle leirer. Hun er ikke bare flink til å håndtere store mengder sakspapirer og krevende møter, hun trakterer også symaskin, alle mulige verktøy og kjører traktoren på gården på Namnå der de bor, to timers kjøring fra Oslo. Kanskje er det vekselvirkningen mellom det rolige livet på landet og hektiske dager i Legenes hus som gir energi til å gyve løs på alle oppgavene hun får og ro dem i land hver gang.

\section{Frankofil attpåklatt}

- For å begynne med begynnelsen - hvorfor ble du lege?

- Det var nok en kombinasjon av det å ha fått gode karakterer og en visshet om at utdanningen kunne brukes til mye forskjellig.

Hermansen kommer ikke fra en legefamilie, far var offiser og mor var sykepleier.

- Mor syntes nok at jeg burde bli lege, men jeg fikk stor frihet hjemmefra til å ta mine egne valg.

Hun vokste opp i Brumunddal. Hennes to brødrene var åtte og elleve år eldre.

- Du er en attpåklatt?

- Den etterlengtede attpåklatten - og jente, sier hun og ler.

\section{Marit Hermansen}

Født 20. mars 1964

Cand.med., Universitetet i Bergen 1992

Spesialist i allmennmedisin 2003

Allmennlege/fastlege i Grue kommune 1996-2016

Leder i Norsk forening for allmennmedisin 2011-15

Nestleder og konstituert leder Akademikerne 2015-16

President i Legeforeningen siden 2015

- Det har vært et godt utgangpunkt i livet. Jeg hadde foreldre med lave skuldre og brødre som passet på meg. Det var en fin oppvekst.

Da hun gikk på videregående skole, reiste hun på utveksling til Auxerre - en liten by midt i Frankrike.

- Jeg hadde lyst til å lære fransk, som jeg overhodet ikke kunne, men jeg lærte fort. Alle de tre barna våre har reist på utveksling, og vi har også hatt tre studenter boende på gården.

Barna er nå i 2o-årene, og det første barnebarnet har kommet.

- En ekstra bonus ved det å pendle til Oslo er at jeg får mer tid med barnebarnet.

Selv bodde Hermansen og familien i Bergen da barna var små, langt fra besteforeldrene. Alle tre barna skarrer fortsatt. Fra Bergen gikk veien videre til gården på Finnskogen.

- Mannen min hadde odel på gården. Da er det lettvint med en ektefelle som er lege og kan jobbe overalt. 


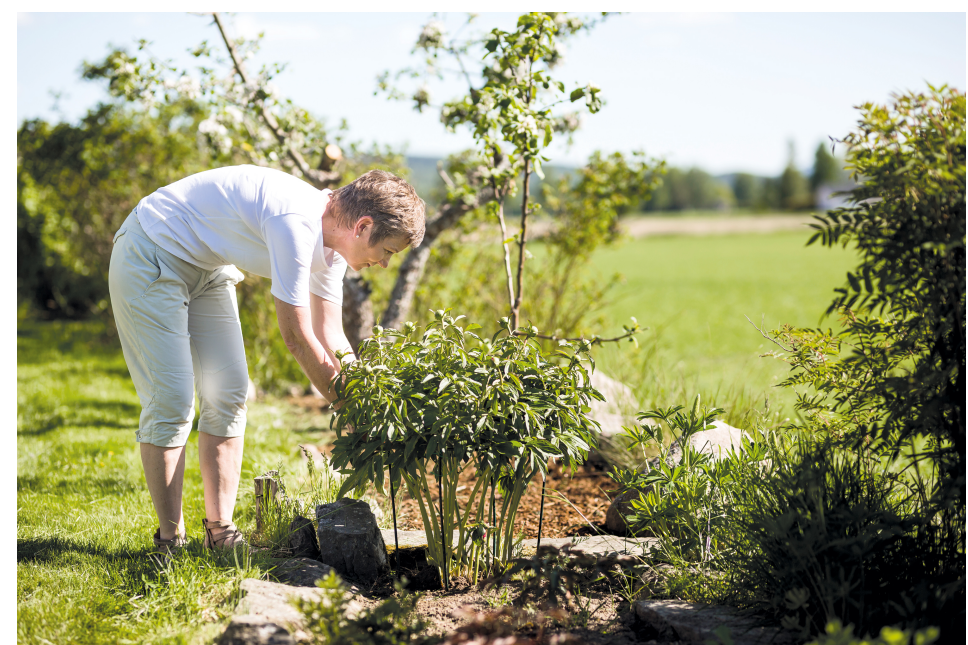

Marit Hermansen liker å dyrke, og i hagen gjør peonene seg klare til blomstring. Foto: Kristine Lindebø

\section{Fastlegeordningens gullalder}

- Var allmennlege et bevisst valg?

- Det var en mulighet som åpnet seg da vi flyttet til gården. Jeg synes jeg har hatt stor innflytelse på egen jobbsituasjon og har vært godt fornøyd med en faglig spennende jobb der jeg bor. Det har ikke vært vanskelig for meg å møte pasienter på butikken, jeg er nok god til å sette grenser både for meg selv og andre.

- Det høres ut som om du har hatt et fint fastlegeliv?

- Jeg var med på å forhandle fastlegeordningen i egen kommune. Oppgaveoverføringen vi har sett, har nok i størst grad kommet til etter at jeg tok permisjon fra jobben for å bli leder i Norsk forening for allmennmedisin i 2011.

- Du fikk med deg gullalderen i fastlegeordningen?

- Ja, det vil jeg si. Jeg ser fortsatt potensialet, men så har det ikke vært vanskelig å forstå hva som har skjedd med ordningen når jeg ser tallene og snakker med kolleger.

- Er det en fastlegekrise i dag?

- Ja, det er ingen overdrivelse, svarer hun raskt. - Det er ulike forhold der ute, men når jeg hører hvor mye folk jobber og har en følelse av å ikke rekke over og aldri gjøre en god nok jobb ... det orker man ikke over tid. Så får jeg alltid spørsmålet om hvorfor vi bruker den retorikken der vi påpeker problemene. Vil vi da klare å rekruttere nye fastleger?

- Hva svarer du da?

- Da svarer jeg at det ikke er retorikk. Vi beskriver virkeligheten, og det tror jeg er viktig for å oppnå forandring. Nå har vi fått på plass en handlingsplan hvor vi har fått gjennomslag for de tiltakene som vi mener er viktigst. Så må vi fortsatt kjempe for tilstrekkelig økonomi for å styrke rekrutteringen av unge flinke leger - og kanskje lokke noen erfarne leger tilbake. 


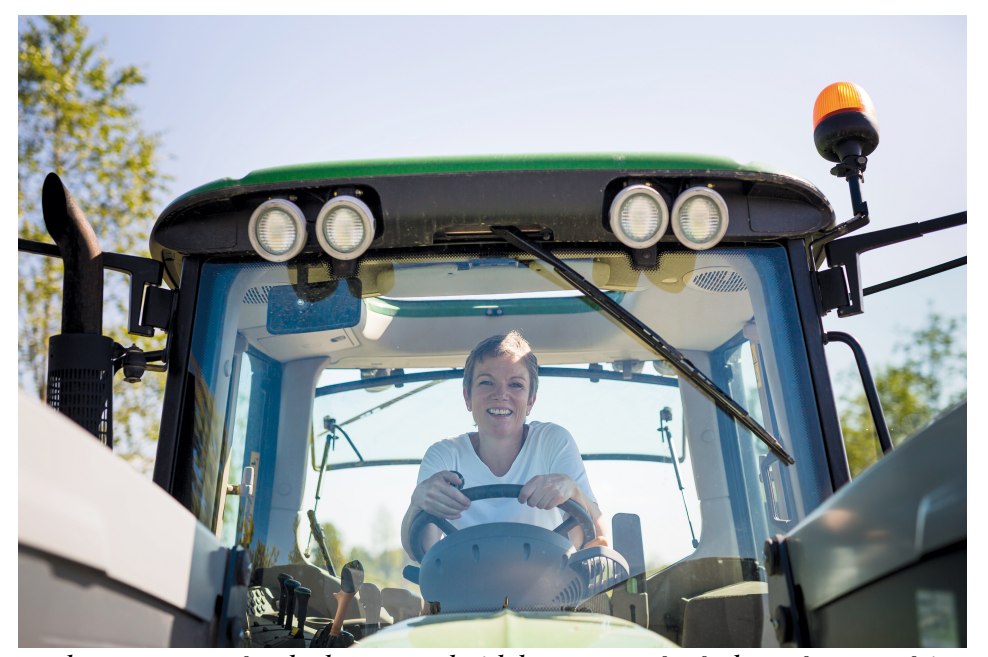

Traktoren er også selvskreven arbeidskamerat på gården på Namnå i Grue kommune. Foto: Kristine Lindebø

- Tror du fastlegeordningen vil bestå?

- Ja, det har vært en god ordning, men ressursoverføringene har ikke fulgt takten på oppgavene. Hadde man fått til den mekanismen tidligere, hadde vi ikke hatt den krisen vi har nå. Fastlegeordningen er en god, billig og effektiv legetjeneste spredd utover det ganske land.

- Har koronaviruset påvirket fastlegekrisen?

- Heller ikke i denne situasjonen har man sett fastlegenes behov. De rigget om virksomheten, stod mye alene og hadde store inntektstap. Det bekymrer meg når ordningen allerede er i krise.

\section{Første fagmedisiner}

- Du er den første presidenten fra den fagmedisinske aksen i foreningen, hvordan har det vært?

- Det har vært krevende på den måten at jeg raskt måtte inn på et område som jeg ikke kjente så godt, nemlig forhandlingsområdet. Jeg har lært mye av solide yrkesforeninger og et veldig kompetent sekretariat. På den annen side opplevde jeg å kjenne organisasjonen bredt. Med bakgrunn fra primærhelsetjenesten kan man hevde at jeg ikke kjenner sykehussiden, men som fastlege får du mye erfaring med spesialisthelsetjenesten. Jeg tenker at fastlegebakgrunn er en god presidentskole. Du er trent $\mathrm{i}$ å forholde deg til nye problemstillinger hver eneste dag, lære mye nytt og støtte deg på andre som kan mye. Det å være president er å være en lagleder. Du får ikke til dette alene.

Fastlegebakgrunn er en god presidentskole

- Legeforeningen er stor, du har sagt at det skal være noe for alle der?

- Noe av det jeg er fornøyd med at vi har fått til, er tydeliggjøring av den fagmedisinske aksen. For leger flest tror jeg det er i faget man har identiteten sin. Og så stoler de på at noen forhandler for dem og ivaretar andre interesser.

- Hvordan har det vært å være president i en pandemi og kanskje den største helsekrisen i moderne historie i landet?

- Jeg er glad det skjedde på min vakt. Jeg kjenner hele foreningen godt og har vært president en god stund nå. Det har vært et stort ansvar, men jeg leder et godt lag.

\section{Streik og pandemi}

Marit Hermansen var fersk president da det ble sykehusstreik.

- Med min bakgrunn ble det en bratt læringskurve da streiken oppsto. Av erfarne kolleger 
lærte jeg utrolig mye om sykehuslegenes hverdag. Streiken var i 2016, arbeidsrettens avgjørelse kom i 2017, og endelig løsning ved forhandling kom i 2018.

- Hva tenker du om sykehuslegenes kår nå? Førte streiken noe med seg?

- Den førte med seg en seier i arbeidsretten som var prinsipielt viktig. Når leger har godtatt så vide unntak fra arbeidsmiljøloven, er det viktig at det er Legeforeningen som setter de ytre rammene. Her snakker vi om virkelig vide rammer som arbeidsgiver kan jobbe innenfor.



I drivhuset som Marit fikk i presang av mannen da hun ble 40 år, spirer det tomatplanter. - I år har jeg rukket å så tomatplanter, siden jeg plutselig hadde hjemmekontor, forteller hun. Foto: Kristine Lindebø

- Hvordan opplever du hverdagen for sykehusleger nå?

- Sykehusbudsjettene har vært veldig stramme, det merker alle ansatte. Også sykehusene får nye oppgaver uten at det følger med midler. Så kom koronaviruset, som har krevd mye av alle. Til slutt handler det om hvor mye vi bruker på helsetjenesten i Norge. Hvor stor del av kaka skal helse utgjøre i samfunnsøkonomien? Vi mener at det er potensial for å bruke en større del på helse hvis vi skal komme forventningene i møte. Det er jo ikke noe i veien med forventningene, understreker hun, og legger til at både politikere og pasienter ønsker gode tjenester.

- Vi har allerede lært at beredskap koster, men at dårlig beredskap koster mer. Det er en viktig lærdom etter koronasituasjonen.

Jeg er glad koronaviruset skjedde på min vakt

- Vi hører stadig at det brukes mye på helse. Hvordan møter dere det?

- Der mener jeg at det har vært en endring. Hvis vi går ti år tilbake i tid, brukte man uttrykk som «bunnløse sluk» og «det er en strikk uten ende». Legeforeningen var en viktig pådriver for å snu denne retorikken da helseministeren bestilte en OECD-rapport som viste at vi ikke nødvendigvis bruker så mye på helse i Norge. Nå er overskriftene heller at

sykehusdirektører er bekymret, at vi har for stramme budsjetter. Det er viktig å se etter muligheter for effektivisering, men helsetjenesten har virkelig effektivisert og leverer mer for hver krone hele tiden. Strikken er strammet nok. Kunnskapen fra koronasituasjonen må få konsekvenser for budsjettene fremover.

- Er du bekymret for en krise blant sykehusleger i tillegg til fastlegekrisen?

- Undersøkelser har vist at helsepersonell generelt og leger spesielt er veldig glade i jobben og strekker seg langt for å levere gode tjenester til pasientene. Det er en stor ressurs for arbeidsgiver å ha ansatte med en slik innstilling, men det må ikke misbrukes. Da koronaviruset kom til Norge, tok helsepersonell utfordringen. Som forening arbeidet vi med å sikre avtalene for en ekstraordinær situasjon og ikke minst sikkerheten for alle som jobber i sykehus. Nå må vi arbeide med å finne gode ordninger for etterslepet på helsehjelp 
som nedstengningen har ført til.

- Har koronaviruset ført til noen positive endringer?

- Det er noe bra med tvangsdigitaliseringen vi alle har vært igjennom. Nå blir det viktig å skaffe kunnskap om hvilke konsultasjoner som kan skje digitalt og hvilke pasienter vi bør treffe på kontoret.

\section{Utbrenthet}

- Tror du vi vil se økende utbrenthet blant leger?

- Leger er generelt lite sykmeldt. Men de legespesialitetene som jobber mye pasientnært, har en høyere andel sykmeldinger. Vi ser også en økning i søknader til vårt helsetilbud for leger, Villa Sana. Det bekymrer meg. Samtidig er det fint at leger søker hjelp når hverdagen blir for tøff. Jeg tror det er viktig å gi mer innflytelse på det kliniske nivået. Vi har spilt inn til nasjonal helse- og sykehusplan at det er viktig å investere, for eksempel i det å ha støttepersonell rundt legene, tjenlige IT-systemer og en sykehusutforming som gjør at man slipper å løpe rundt og lete etter pasientene. Det er personellet som er dyrest i Helse-Norge, vi må investere slik at vi får utnyttet ressursene. Da får man flere legetimer og gladere ansatte.

Det året det var streik, frøs 120 georginer

- Hvordan forebygger du selv utbrenthet?

Hun ler, og tanken virker nok ganske fjern.

- Er det noe jeg har, så er det autonomi, svarer hun blidt. Jeg er privilegert som i stor grad kan styre min egen hverdag.

- Hvordan får du påfyll da?

- Jeg er god til å konsentrere meg om det jeg driver med og ta én ting om gangen. Det er en god egenskap i denne jobben. Og så er jeg god til å slappe av når jeg har mulighet. Aller best har jeg det sammen med familien min. I vintersesongen liker jeg godt å gå på ski, og vi er mye på hytta på Skei.

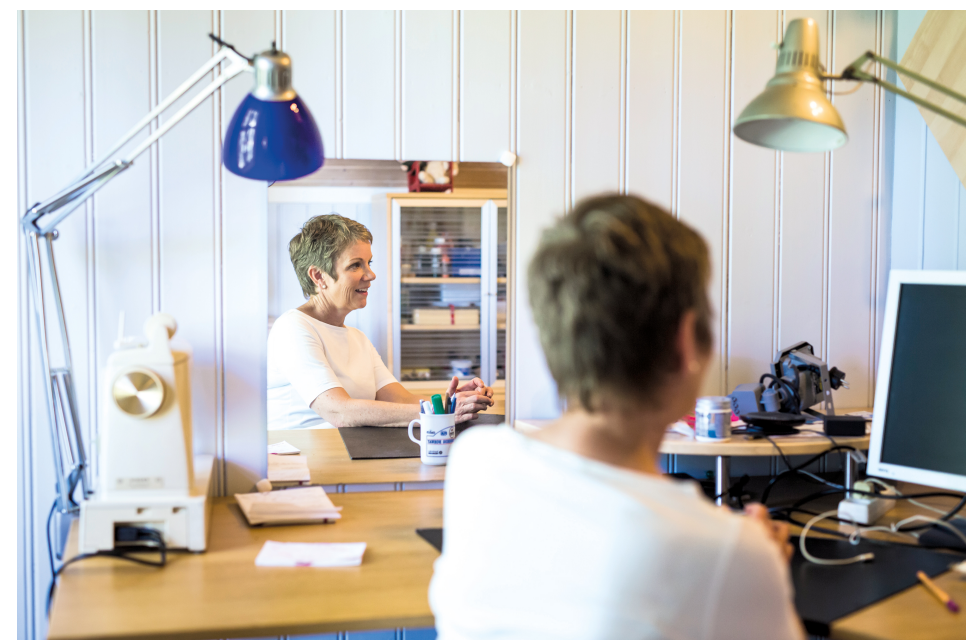

Sønnens gutterom ble til hjemmekontor da Norge stengte ned.Ved skrivebordet står en kontorstol med kamuflasjemønster, oppå bordet en symaskin, i tillegg til dataskjermer og flere lamper-som scerlig ble brukt da hun skulle på direkten på NRK. Foto: Kristine Lindebø

- Du smører skiene til mannen din?

- Jeg liker vel å ha kontroll. Og så liker jeg å ha gode ski, ja, at vi begge har det. Lars er min beste turkamerat.

I tillegg til å like å gli fort i nedoverbakke i skiløypa, liker hun å dyrke.

- Jeg har et relativt stort drivhus, men det er bare til eget bruk. 
Drivhuset fikk hun i presang av mannen da hun ble 40 år.

- Det går litt i perioder. En stund drev jeg med georginer. De må graves opp om høsten og lagres inne, og så setter du de ut om våren. Det året det var streik, frøs 120 georginer. I år har jeg rukket å så tomatplanter, siden jeg plutselig hadde hjemmekontor.

\section{Den røde tråden}

Hermansen omtales som en president med god politisk innsikt og teft.

- Både som fastlege og som tillitsvalgt må man være interessert i mennesker og den menneskelige dynamikken. Når man vil påvirke i politikken, må man forstå hva som foregår. Vi får til mer sammen enn hver for oss.

- Du har ikke vært politisk aktiv selv?

- Ikke tradisjonelt partipolitisk aktiv, men jeg har alltid vært samfunnsmessig engasjert. Engasjement har vært en rød tråd i livet. Jeg har vært kommuneoverlege samtidig som jeg har vært fastlege. Det er en kombinasjon jeg har likt veldig godt, både fordi arbeidsoppgavene er varierte og fordi man får bidra til lokalsamfunnet.

- Du har halvannet år igjen som president. Er det noe du håper å få til i løpet av den tiden? Svaret kommer lynkjapt.

- En bærekraftig fastlegeordning. Vi gjør en stor innsats for å få til det. Hvor godt handlingsplanen nå blir fulgt opp, avgjør skjebnen til fastlegeordningen, også etter koronavirusets inntreden. Så håper jeg at vi klarer å være en god organisasjon for våre medlemmer og tillitsvalgte og fortsette arbeidet med å tydeliggjøre den fagmedisinske aksen. Jeg er også opptatt av at vi får en forståelse for at vi må investere i sykehusene og beredskap hvis vi skal ha en god offentlig helsetjeneste for alle. Aldri har vel betydningen av en sterk offentlig helsetjeneste vist seg tydeligere enn i disse ukene.

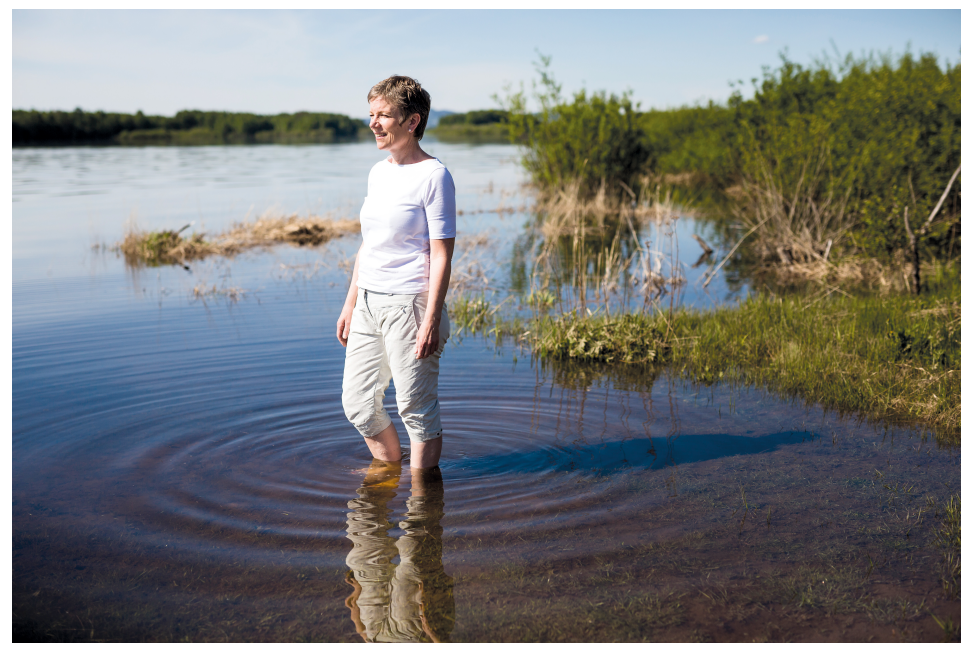

Gården ligger like ved Glomma. Nå er elva flomstor, men senere på sommeren fyller Marit traktoren med strandstoler og annet strandutstyr og kjører de fem minuttene ned til kilometervis med sandstrand for å bade og nyte sola. Foto: Kristine Lindebø

- Hva er løsningen?

- Det er bare gjennom å levere varene godt i det offentlige at vi kan motvirke en todelt helsetjeneste.

- Det er store mål du har satt deg?

- Det er det, men Legeforeningen er en viktig premissleverandør. Vi har en viktig samfunnsrolle og et stort ansvar. Det ble ekstra tydelig da koronaviruset kom til landet.

- Er du glad du ble lege?

- Jeg er veldig fornøyd. 
- Er du bekymret for hvordan samfunnet vårt blir påvirket av koronaviruset fremover?

- Jeg tror ikke vi får et kaldt, distansert samfunn. Menneskemøtene kommer gradvis tilbake, men kanskje blir vi mer takknemlige enn før over det å få sitte rundt et bord sammen med andre.

Publisert: 29. juni 2020. Tidsskr Nor Legeforen. DOI:10.4045/tidsskr.20.0196

(C) Tidsskrift for Den norske legeforening 2020. Lastet ned fra tidsskriftet.no 